\title{
ANALISIS PENGENDALIAN KUAITAS PRODUK PAP HANGER MENGGUNAKAN METODE SIX SIGMA DAN FMEA DI PT. RAVANA JAYA MANYAR GRESIK
}

\author{
M. Bachtiar ${ }^{1}$, Said Salim Dahdah', dan Elly Ismiyah ${ }^{3}$ \\ Program Studi Teknik Industri, Fakultas Teknik, Universitas Muhammadiyah Gresik \\ Jl. Sumatera 101 GKB, Gresik 61121, Indonesia \\ Bachtiarbach329@gmail.com
}

\begin{abstract}
Kualitas produk menjadi salah satu keunggulan kompetitif dari industry yang harus terus dikelola dengan baik. Termasuk pada industri yang menjalankan aktifitasnya dengan menerima pesanan perlu mengidentifikasi akfitas apa saja yang sering mengalami kegagalan dalam menghasilkan produk sesui dengan spesifikasi. Studi kasus pada perusahaaan yang bergerak di bidang konstruksi dan fabrikasi. Salah satu produk yang dihasilkan Pap Hanger, pada bagian cutting provile dan painting didapatkan jumlah kecacatan produk yang tinggi dimana tingkat kecacatan mencapai 12, 75\% dan melebihi batas toleransi yang di tetapkan perusahaan yakni $4,5 \%$. Untuk mengatasi permasalahan ini digunakan metode six sigma dan FMEA digunakan untuk mengetahui nilai kinerja pengendalian kualitas berdasarkan nilai sigma, selain itu juga dicari penyebab terbesar dari kegagalan yang menjadi pemicu persoalan tersebut. Contoh perhitungan pada produk pap hanger telah disajikan pada akhir penelitian ini serta penyebab kecacatan dominan yang disebabkan kegagalan proses.
\end{abstract}

Kata kunci : Cacat Produk, DMAIC, FMEA, Six Sigma. 


\section{PENDAHULUAN}

\subsection{Latar Belakang}

Salah satu kunci sukses memenangkan persaingan industri kedepan di era globalisasi adalah dengan memperhatikan masalah kualitas dan tepat waktu dalam penyelesaian, kualitas merupakan karakteristik produk atau jasa yang dituntut oleh pemakai atau customer dan diperoleh melalui pengukuran proses serta perbaikan yang berkelanjutan. Oleh karena itu jika suatu perusahaan ingin tetap bertahan, terutama dalam menghadapi era globalisasi, diharuskan memperhatikan kualitas secara kontinyu, menjaga kestabilan dan memperbaiki kekurangan proses produksi yang berlangsung. Hal ini mengindikasikan bahwa perusahaan tidak hanya fokus pada kualitas produk, akan tetapi juga meningkatkan kualitas pada aspek lainnya yang termasuk dalam sistem perusahaan. Seperti halnya, kualitas bahan baku dari pemasok, kualitas tenaga kerja, kualitas mesin dan teknologi yang digunakan, sistem pemasaran yang efektif, serta sistem distribusi yang tepat waktu. Garvin (1988) mendefinisikan kualitas sebagai suatu kondisi dinamis yang berhubungan dengan produk, manusia/tenaga kerja, proses dan tugas, serta lingkungan yang memenuhi atau melebihi harapan pelanggan atau konsumen.

PT. Ravana Jaya merupakan perusahaaan yang bergerak di bidang konstruksi dan fabrikasi. Pada perusahaan PT. Ravana Jaya melakukan serangkaian pekerjaan dari beberapa komponen dan disatukan menjadi satu komponen utuh yang diminta oleh pelanggan. Salah satu produk yang dihasilkan oleh PT. Ravana Jaya yang diperuntukan PT. Freeport Inonesia berupa produk pap hanger. Dari hasil pengamatan masih terdapat permasalahan dalam produksi pap hanger tersebut terutama pada masalah kualitas seperti pada bagian painting dan cutting Provile, masalah seperti ini masih sering di temui pada PT. ravana jaya sehingga akan menyebabkan ketidak puasan konsumen Jika terjadi hal sedemikian rupa maka Quality control akan mengarahkan produk cacat tersebut untuk dilakukan pembenahan. Dampak bagi perusahaan adalah mengakibatkan perusahaan mengalami kerugian karena harus mengeluarkan biaya tambahan untuk reparasi.

\subsection{Tujuan}

Tujuan dari penelitian ini adalah untuk mengetahui potensial kecacatan produk serta dampak dari kecacatan produk, membuat rekomendasi usulan perbaikan pada departemen operasional pada pembuatan produk pap hanger.

\subsection{Metode Penelitian}

Objek penelitian ini dilakukan pada proses produksi pap hanger di PT. Ravana Jaya, metode yang digunakan yaitu Six Sigma untuk mengukur Sigma Quality Level (SQL), kemudian mencari akar penyebab kegagalan dengan diagram Fishbon dengan atribut didapatkan melalui wawancara, kemudian menentukan prioritas perbaikan menggunakan FMEA (Failure Mode And Analysis) yang mana nilai Saverity, occurance dan Detection di dapatkan melalui penyebaran kuisioner.

\section{TINJAUAN PUSTAKA}


Pap hanger atau gantungan yang terbuat dari besi baja ini berfungsi sebagai tempat gantungan sebuah pipa air berukuran besar yang di letakan didalam lubang tambang yang nantinya berfungsi untuk mengalirkan air ke dalam lubang galian, model dari hanger ini seperti huruf $\mathrm{T}$ bahan untuk membuat produk ini adalah sebuah balok leter $\mathrm{L}$ dengan ketebalan $2 \mathrm{~cm}$ dengan lebar $15 \mathrm{~cm}$ dan Panjang $120 \mathrm{~cm}$. Contoh ganbar Produk pap Hanger sebagai berikut:

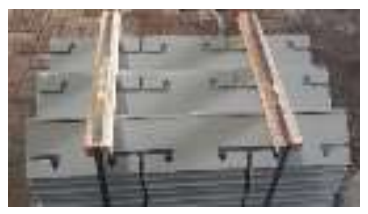

\section{Gambar 1 Pap Hanger}

\subsection{Six Sigma}

Six sigma merupakan suatu sistem yang fleksibel untuk mencapai, mempertahankan, dan memaksimalkan kesuksesan dalam berbisnis. Six sigma secara unik dikendalikan oleh pemahaman yang kuat terhadap kebutuhan pelanggan, pemakaian yang disiplin terhadap fakta, data, analisis statistik, dan perhatian yang cermat untuk mengelola, memperbaiki, dan menanamkan kembali proses bisnis. Sejak tahun 1920an, kata "sigma" telah dipergunakan oleh para ilmuan sebagai suatu simbol untuk suatu unit pengukuran dalam variasi kualitas produk. (Gasperz, 2002).

Pada dasarnya pelanggan akan puas apabila mereka menerima nilai sebagaimana yang mereka harapkan. Apabila produk (barang /jasa) diproses pada tingkat kualitas $\backslash$ Six Sigma, perusahaan mengharapkan 3,4 kegagalan per sejuta kesempatan (DPMO) atau mengharapkan bahwa 99,99966 persen dari apa yang diharapkan pelanggan akan ada dalam produk itu.

.Tabel 1. Pencapaian Beberapa Tingkat Sigma

\begin{tabular}{|c|c|c|c|}
\hline $\begin{array}{l}\text { Proses yang } \\
\text { memenuhi } \\
\text { spesifikasi }\end{array}$ & DPMO & $\begin{array}{l}\text { Level } \\
\text { Sigma }\end{array}$ & Keterangan \\
\hline $31 \%$ & 691.462 & 1-sigma & $\begin{array}{c}\text { Sangat tidak } \\
\text { kometitif }\end{array}$ \\
\hline $69.20 \%$ & 308.538 & 2-sigma & \multirow{2}{*}{$\begin{array}{l}\text { Rata-rata } \\
\text { industry } \\
\text { indonesia }\end{array}$} \\
\hline $93.32 \%$ & 66.807 & 3-sigma & \\
\hline $99.379 \%$ & 6.210 & 4-sigma & \multirow{2}{*}{$\begin{array}{c}\text { Rata-rata idustri } \\
\text { USA }\end{array}$} \\
\hline $99.977 \%$ & 233 & 5-sigma & \\
\hline $99.997 \%$ & 3.4 & 6-sigma & $\begin{array}{c}\text { Industri kelas } \\
\text { dunia }\end{array}$ \\
\hline
\end{tabular}

Sumber (Gasperz, 2002)

Six sigma merupakan sebuah metode perbaikan kualitas yang berbasis statistik yang memerlukan disiplin tinggi dan dilakukan secara komprehensif dan fleksibel untuk mencapai, mempertahankan, dan memaksimalkan sukses bisnis dengan mengeleminasi sumber masalah utama menggunakan pendekatan Define Measure Analyze Improve Control (DMAIC). Pendekatan DMAIC tersebut juga merupakan tahapan dalam analisis six sigma.

\section{1.) Define}

Tahap Define merupakan langkah operasional pertama dalam program peningkatan kualitas Six Sigma. Dalam tahap Define dilakukan identifikasi potensial, mendefinisikan peran orang-orang yang terlibat dalam proyek Six Sigma, mengidentifikasi karakteristik kualitas kunci (CTQ) yang berhubungan langsung dengan kebutuhan spesifik dari pelanggan dan menentukan tujuan. 
2.) Measure

Measure merupakan langkah operasional kedua dalam program peningkatan kualitas Six Sigma, terdapat beberapa hal pokok yang harus dilakukan yaitu: mengumpulkan data Critical To Quality (CTQ) merupakan elemen dari suatu produk, proses, atau praktekpraktek yang berdampak langsung pada kepuasan pelanggan. Kemudian mencari nilai DPO Defect Per Opportunities yang merupakan ukuran kegagalan yang dihitung dalam program peningkatan kualitas Six Sigma, yang menunjukkan banyaknya cacat atau kegagalan per satu kesempatan, dan dihitung dengan formula:

$$
\text { DPO }=\frac{\text { Jumlah Defect }}{\text { Unit yang di inspeksi } x \text { CTQ }}
$$

Sumber: Gasprez (2002) dalam Wahyu Djalmono.

Defect per Million Opportunities (DPMO) merupakan ukuran kegagalan dalam program peningkatan Six Sigma, yang menunjukkan kegagalan per satu juta kesempatan. Besarnya DPO apabila dikalikan dengan konstanta 1.000 .000 akan menjadi formula:

$$
\text { DPMO }=\frac{\text { Jumlah Defect }}{\text { Unit yang di inspeksi } x \text { CTQ }} \times 1.000 .000
$$

Sumber: Gasprez (2002) dalam Wahyu Djalmono.

Tingkat sigma sering dihubungkan dengan kapabilitas proses, yang dihitung dalam defect per milion opportunities yang bisa dihitung menggunakan formula.

$$
\text { Nilai sigma }=\frac{\text { NORMSINV }(1.000 .000-\text { DPMO })}{1.000 .000}+1,5
$$

Sumber: Gesprez(2002) dalam Nadifa. (laporan pkl)

\section{Analysis}

Tahap ini focus pada cara mengukur proses internal yang mempengaruhi CTQ dan dilakukan pengukuran berdasarkan tingkat kemampuan proses berasarkan DPMO.

\section{Improve}

Setelah sumber-sumber dan akar penyebab permasalahan kualitas teridentifikasi, maka perlu dilakukan penentapan rencana tindakan (action plan) untuk melaksanakan peningkatan kualitas Six Sigma, yaitu dengan tools: Failure Mode and Effect Analysis (FMEA) yang mendiskripsikan tentang alternatif yang dilakukan dalam implementasi dari rencana itu.

5. Control

Tahap koctrol atau pengendalian ini focus pada bagaimana menjaga perbaikan agar terus berlangsung, termasuk menempatkan perangkat pada tempatnya untuk meyakinkan agar variabel utama tetap berada dalam wilayah maksimal yang dapat diterima dalam proses yang sedang dimodifikasi.

\subsection{FMEA}

FMEA atau analisis mode kegagalan dan efek adalah suatu prosedur terstruktur untuk mengidentifikasi dan mencegah sebanyak mungkin mode kegagalan. Suatu metode kegagalan adalah apa saja yang termasuk dalam kecacatan/kegagalan dalam desain, kondisi diluar batas spesifikasi yang ditetapkan, atau perubahan-perubahan dalam produk yang menyebabkan terganggunya fungsi dari produk itu. Langkah penyelesaian fmea sebagai berikut:

1. Mengidentifikasi proses atau produk/jasa. 
2. Mendaftarkan masalah-masalah potensial yang dapat muncul, efek dari masalah-masalah potensial tersebut dan penyebabnya.

3. Menilai masalah untuk keparahan (severity), probabilitas kejadian (occurance) dan detektabilitas (detection).

4. Menghitung Risk Priority Number atau RPN yang rumusnya adalah dengan mengalikan ketiga variabel dengan poin 3 diatas dan menentukan rencana solusi-solusi priorita yang harus dilakukan. $\mathrm{RPN}=\mathrm{S} \times \mathrm{O}$ x D.

Service FMEA digunakan untuk menganalisa servis sebelum mencapai ke konsumen. Servis FMEA fokus pada kegagalan yang disebabkan oleh sistem atau proses (Stamatis, 2003). Untuk dapat menghitung nilai RPN dari suatu proses, nilai Saverity, Occurrence, dan Detection harus diketahui. Pengukuran terhadap nilai severity, occurrence, dan detection adalah sebaga berikut 1. Severity

Severity adalah langkah untuk menganalisa risiko yaitu menghitung seberapa besar dampak/intensitas kejadian mempengaruhi output proses. Dampak tersebut diranking mulai 1 sampai 10, dimana 10 merupakan dampak terburuk.

Tabel 2. Current Process Control Severity

\begin{tabular}{|c|l|}
\hline Rank & \multicolumn{1}{|c|}{ Kriteria } \\
\hline 1 & Tidak terlihat oleh operator (Proses/Produk) \\
\hline 2 & $\begin{array}{l}\text { Efek tidak berarti / diabaikan (Proses). Efek } \\
\text { tidak signifikan / tidak berarti (Produk). }\end{array}$ \\
\hline 3 & $\begin{array}{l}\text { Operator mungkin akan melihat efeknya } \\
\text { namun efeknya kecil (Proses dan Produk). }\end{array}$ \\
\hline 4 & $\begin{array}{l}\text { Proses lokal dan/atau hilir mungkin } \\
\text { terpengaruh (Proses). Pengguna akan } \\
\text { mengalami dampak negatif kecil pada produk } \\
\text { (Produk). }\end{array}$ \\
\hline
\end{tabular}

\begin{tabular}{|c|c|}
\hline 5 & $\begin{array}{l}\text { Dampak akan terlihat sepanjang operasi } \\
\text { (Proses). Mengurangi kinerja dengan } \\
\text { penurunan kinerja secara bertahap. } \\
\text { Pengguna tidak puas (Produk). }\end{array}$ \\
\hline 6 & $\begin{array}{l}\text { Gangguan terhadap proses hilir (Proses). } \\
\text { Produk bisa dioperasikan dan aman namun } \\
\text { kinerjanya menurun. Pengguna tidak puas } \\
\text { (Produk). }\end{array}$ \\
\hline 7 & $\begin{array}{l}\text { Downtime yang signifikan (Proses). Kinerja } \\
\text { produk sangat terpengaruh. Pengguna sangat } \\
\text { tidak puas (Produk). }\end{array}$ \\
\hline 8 & $\begin{array}{l}\text { Downtime signifikan dan berdampak pada } \\
\text { keuangan (Process). Produk tidak bisa } \\
\text { dioperasikan tapi aman. Pengguna sangat } \\
\text { tidak puas (Produk) }\end{array}$ \\
\hline 9 & $\begin{array}{l}\text { Kegagalan yang mengakibatkan efek } \\
\text { berbahaya sangat mungkin terjadi. } \\
\text { Masalah keamanan dan regulasi (Proses } \\
\text { dan Produk). }\end{array}$ \\
\hline 10 & $\begin{array}{l}\text { Kegagalan yang mengakibatkan efek } \\
\text { berbahaya hampir pasti. Tidak } \\
\text { mengakibatkan cedera atau membahayakan } \\
\text { personil operasi (Process). Kepatuhan } \\
\text { terhadap peraturan pemerintah (Produk). }\end{array}$ \\
\hline
\end{tabular}

Sumber: (Visent Gaspert, 2002)

\section{Occurance}

Occurence adalah kemungkinan bahwa penyebab tersebut akan terjadi dan menghasilkan bentuk kegagalan selama masa penggunaan produk. Dengan memperkirakan kemungkinan occurence pada skala 1 sampai 10.

Tabel 3. Current Process Control Occurance

\begin{tabular}{|c|c|c|}
\hline $\begin{array}{c}\text { Probability } \text { Of } \\
\text { Failure }\end{array}$ & Filure Rates & Rating \\
\hline \multirow{2}{*}{ Sangat Tinggi } & 1 in 2 & 10 \\
\cline { 2 - 3 } & 1 in 3 & 9 \\
\hline \multirow{2}{*}{ Tinggi } & 1 in 8 & 8 \\
\cline { 2 - 3 } & 1 in 20 & 7 \\
\hline \multirow{2}{*}{ Sedang } & 1 in 80 & 6 \\
\cline { 2 - 3 } & 1 in 400 & 5 \\
\hline Rendah & 1 in 2000 & 4 \\
\hline Sangat Rendah & 1 in 15000 & 3 \\
\hline Remote & 1 in 1500000 & 1 \\
\hline
\end{tabular}

Sumber: (Visent Gaspert, 2002)

\section{Detection}

Nilai Detection diasosiasikan dengan pengendalian saat ini. Detection adalah pengukuran terhadap kemampuan 
mengendalikan/mengontrol kegagalan yang dapat terjadi.

Tabel 4. Current Process Control Detection

\begin{tabular}{|c|c|c|c|}
\hline Detection & $\begin{array}{c}\text { Criteria } O f \\
\text { Detection By } \\
\text { Process }\end{array}$ & $\% R \& R$ & Rangking \\
\hline $\begin{array}{c}\text { Hampir } \\
\text { tidak } \\
\text { mungkin }\end{array}$ & $\begin{array}{c}\text { Tidak ada alat } \\
\text { pengontrol yang } \\
\text { mendeteksi }\end{array}$ & $\geq 100 \%$ & 10 \\
\hline $\begin{array}{l}\text { Sangat } \\
\text { jarang }\end{array}$ & $\begin{array}{c}\text { Alat pengontrol } \\
\text { yang sangat sulit } \\
\text { dipahami } \\
\text { sehingga } \\
\text { menimbulkan } \\
\text { kegagalan }\end{array}$ & $\geq 100 \%$ & 9 \\
\hline Jarang & $\begin{array}{c}\text { Alat pengontrol } \\
\text { saat sulit } \\
\text { mendeteksi } \\
\text { bentuk dan } \\
\text { penyebab } \\
\text { kegagalan sangat } \\
\text { rendah }\end{array}$ & $\geq 80 \%$ & 8 \\
\hline $\begin{array}{l}\text { Sangat } \\
\text { rendah }\end{array}$ & $\begin{array}{c}\text { Kemampuan } \\
\text { control untuk } \\
\text { mendeteksi } \\
\text { bentuk dan } \\
\text { penyebab } \\
\text { kegagalan sangat } \\
\text { rendah } \\
\end{array}$ & $\geq 80 \%$ & 7 \\
\hline Rendah & $\begin{array}{c}\text { Kemampuan } \\
\text { control untuk } \\
\text { mendeteksi } \\
\text { bentuk dan } \\
\text { penyebab } \\
\text { kegagalan rendah }\end{array}$ & $\geq 60 \%$ & 6 \\
\hline Sedang & $\begin{array}{l}\text { Kemampuan alat } \\
\text { control untuk } \\
\text { mendeteksi } \\
\text { bentuk dan } \\
\text { penyebab } \\
\text { kegagalan sedang }\end{array}$ & $\geq 60 \%$ & 5 \\
\hline $\begin{array}{l}\text { Agak } \\
\text { tinggi }\end{array}$ & $\begin{array}{c}\text { Kemampuan alat } \\
\text { control untuk } \\
\text { mendeteksi } \\
\text { bentuk dan } \\
\text { penyebab } \\
\text { kegagalan sangat } \\
\text { tinggi }\end{array}$ & $\geq 30 \%$ & 4 \\
\hline Tinggi & $\begin{array}{l}\text { Kemampuan alat } \\
\text { control untuk } \\
\text { mendeteksi } \\
\text { bentuk dan } \\
\text { penyebab } \\
\text { kegagalan tinggi }\end{array}$ & $\geq 30 \%$ & 3 \\
\hline $\begin{array}{l}\text { Sangat } \\
\text { tinggi }\end{array}$ & $\begin{array}{c}\text { Kemampuan alat } \\
\text { control untuk } \\
\text { mendeteksi } \\
\text { bentuk dan } \\
\text { penyebab } \\
\text { kegagalan sangat } \\
\text { tinggi }\end{array}$ & $\geq 30 \%$ & 2 \\
\hline $\begin{array}{l}\text { Hampir } \\
\text { pasti }\end{array}$ & $\begin{array}{l}\text { Kemampuan alat } \\
\text { control untuk }\end{array}$ & $\geq 30 \%$ & 1 \\
\hline
\end{tabular}

\begin{tabular}{|l|c|l|l|}
\hline & $\begin{array}{c}\text { mendeteksi } \\
\text { bentuk dan } \\
\text { penyebab } \\
\text { kegagalan }\end{array}$ & & \\
& hampir pasti & & \\
\hline
\end{tabular}

Sumber: (Visent Gaspert, 2002)

Perhitungan nilai RPN dengan cara mengalikan severity Occurance dan detection kemudian mengurutkan nilai RPN mulai terbesar ke terkecil untuk kemudian digunakan sebagai acuan untuk dilakukan usulan perbaikan untuk mengurangi kecacatan produk. $\mathrm{RPN}=\mathrm{S} \times \mathrm{O} \times \mathrm{D}$

\section{ANALISIS DAN PEMBAHASAN}

\subsection{Pengumpulan Data}

Data yang digunakan pada penelitian ini adalah data produksi dan data cacat produksi pap hanger bagian cutting provile dan painting yang didapatkan melalui pengamatan di lapangan secara langsung. Data yang digunakan adalah data produksi dan data cacat produksi per hari dan pengamatan dilakukan selama 30 hari oleh peneliti selama bulan maret 2021 .

\subsection{Pengolahan Data}

Pengolahan data dilakukan menggunakan metode six sigma dengan menggunakan pendekatan Difin, Measure, Analysis, Improve (DMAI). Pendekatan tersebut merupakan sutau Langkah untuk mengetahui nilai sigma dari masing-masing masalah untuk kemudian dilakukan Langkah mencari solusi perbaikan menggunakan pendekatan Diagram Fishbon dan FMEA pada bagian Cutting Provile Dan bagian Painting di PT. Ravana Jaya.

\section{Define}


Tabel 5. Data cacat produk Pap Hanger

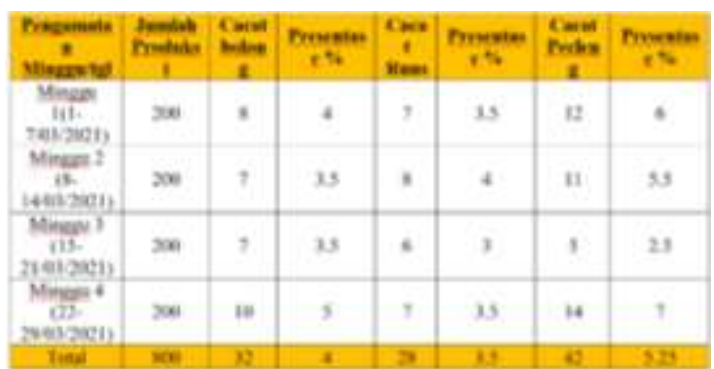

Dari data pada table diatas dapat disimpulkan terdapat tiga jenis cacat produksi yaitu objek cacat bolong terjadi pada proses cutting provile sebesar 32 atau 4,0\%, cacat runs pada proses painting sebesar 28 atau 3,5\%, dan cacat peeleng pada proses painting sebesar 42 atau 5,2\%. Dari ketiga jenis cacat tersebut jenis cacat peeleng memiliki tingkat kecacatan paling tinggi, hal ini mengakibatkan pelanggan atau konsumen melakukan komplain karena produk yang dipesan mengalami kecacatan sehingga perusahaan harus melakukan repair terhadap produk yang cacat sehingga mengakibatkan perusahaan harus mengeluarkan biaya tambahan untuk pembenahan produk yang cacat.

Tahap define adalah tahapan awal dalam metode six sigma, pada tahap ini suatu permasalah yang terjadi di definisikan. Saat ini persaingan industri di bidang fabrikasi mulai diminiati para usahawan. Dan kualitas produk jadi digunakan sebagai acuan para konsumen untuk memilih perusahaan an mana yang memiliki kualitas terbaik baik dari segi kualitas produk, kualitas service dan ketepatan waktu penyelesaian. Permintaan pelanggan inilah yang harus dipenuhi oleh perusahaan demi kepuasan pelanggan.
Pada perakteknya di PT. Ravana Jaya masih terdapat banyak produk cacat pada bagian cutting provile serta painting, terutama pada produk pap hanger yang merupakan produk pesanan konsumen.

\section{Measure}

Tahap ke dua dalam metode six sigma adalah measure atau pengukuran. Pengukuran dilakukan untuk mengetahui potensi kegagalan teresar dengan perhitungan defect permilion opportunity.

\section{a. Penentuan Critical To Quality (CTQ)}

Berdasarkan data inspeksi proses produksi maka ditentukan Critical To Quality untuk defect produk pap hanger sebanyak 3 .

Tabel 6. Critical To Quality

\begin{tabular}{|c|c|l|}
\hline No & Defect & \multicolumn{1}{|c|}{ Keterangan } \\
\hline 1 & Bolong & $\begin{array}{l}\text { Terdapat lubang di tepi } \\
\text { dihasilkan dari mesin cutting } \\
\text { provile }\end{array}$ \\
\hline 2 & Runs & Cat menggumpal di satu titik \\
\hline 3 & Peeleng & $\begin{array}{l}\text { Keadaan cat yang sudah kering } \\
\text { terkelupas akibat cat } \\
\text { kemasukan pasir silika }\end{array}$ \\
\hline
\end{tabular}

b. Perhitungan Sigma Quality Level (SQL)

Pada tahap ini dilakukan pengukuran Sigma Quality Level bertujuan untuk mengetahui sejauh mana proses produksi mampu melakukan produksi produk sesuai yang telah ditentukan. Dalam pengukuran SQL yang bertujuan untuk menentukan nilai sigma maka digunakan satuan DPMO (Defect Per Milion Opportunity ). Perhitungan Sigma Quality Level sebagai berikut:

Tabel 7. Sigma Quality Level 


\begin{tabular}{|c|c|c|c|}
\hline Tatap & Tiesetou: & Fersemsas & most \\
\hline 1 & Proses as yare di aviakan & . & $\begin{array}{l}\text { Enoditai Rap } \\
\text { Hatizas }\end{array}$ \\
\hline 2 & 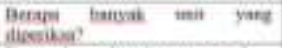 & - & 200 \\
\hline i & 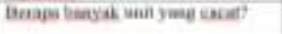 & - & 102 \\
\hline 4 & 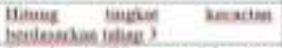 & 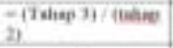 & -8.127 \\
\hline 5 & 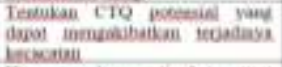 & . & -3 \\
\hline 6 & 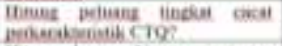 & $\begin{array}{l}\text { Fratiandy those } \\
x^{2}\end{array}$ & $=0.0428$ \\
\hline Y & 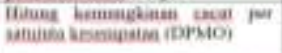 & $\begin{array}{l}\text { Thaspein } \\
\text { i Doo } 000\end{array}$ & -22000 \\
\hline 5 & 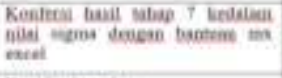 & 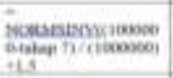 & 121 \\
\hline " & Ban ansaupan & . & 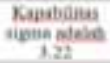 \\
\hline
\end{tabular}

Table 8. Hasil Perhitungan DPMO

\begin{tabular}{|c|c|c|c|c|c|c|}
\hline Data Mlinaz: & $\begin{array}{c}\text { Frodakad } \\
\text { (anin) }\end{array}$ & Defect & $\begin{array}{l}\text { Hanyak } \\
\text { CTO }\end{array}$ & Dro & Drsto & Segma \\
\hline $\begin{array}{l}\text { Nences I } \\
\text { toi- } \\
\text { mo2 }\end{array}$ & 260 & 27 & 3 & 20.55 & 45000 & 3.195 \\
\hline $\begin{array}{l}\frac{\text { Ninga: } 2}{(66)} \\
1400 / 2021)\end{array}$ & 200 & 26 & 3 & 0.0433 & 4313333 & 3213 \\
\hline $\begin{array}{l}\text { Mineon } 3 \\
\text { (BK } \\
23032025)\end{array}$ & 300 & 18 & 3 & 003 & 30000 & 3351 \\
\hline 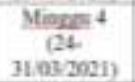 & 300 & 31 & 3 & a 0517 & 51666.67 & 3129 \\
\hline Tetal & 200 & 162 & & & & \\
\hline Rata-rate & 200 & 25.5 & 3 & eons & 42800 & 3130 \\
\hline
\end{tabular}

Data pada tabel 8. Akan dibuat grafik nilai DPMO dan nilai Sigma sebagai berikut:

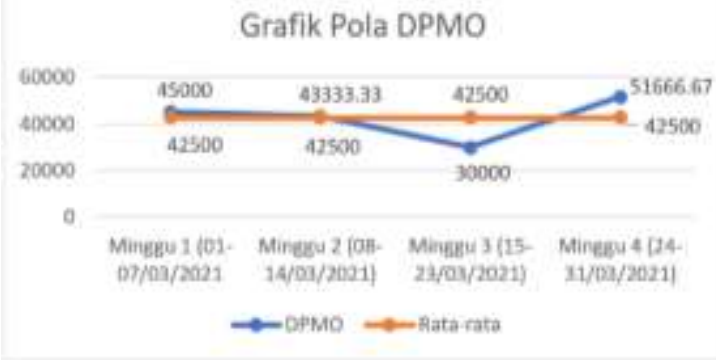

Gambar 2. Analisis Grafik DPMMO

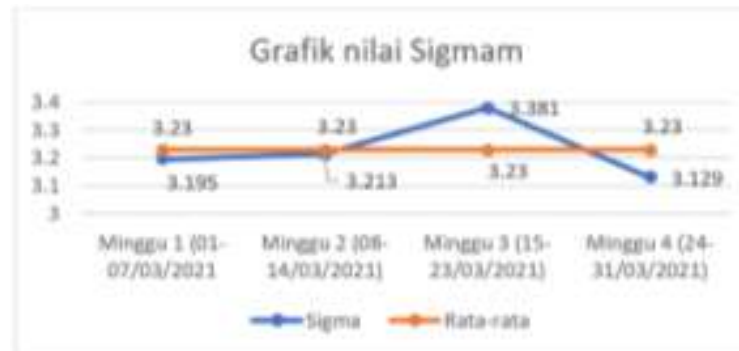

Gambar 3. Analisis Grafik SQL

\section{Analysis}

Berikut data defect dari masing-masing CTQ kemudian di komulatifkan dan di analisis menggunakan diagram pareto untuk lebih mudah melihat potensial defect yang di hasilkan PT. Ravana Jaya dalam pembuatan Pap Hanger.

Tabel 9. Data CTQ dan Presentase kumulatif

\begin{tabular}{|l|l|r|r|r|}
\hline No & CTQ & $\begin{array}{c}\text { Jumbh } \\
\text { cacat } \\
\text { (unit) }\end{array}$ & $\begin{array}{c}\text { Presentase } \\
\%\end{array}$ & $\begin{array}{c}\text { Persen } \\
\text { kumulatif }\end{array}$ \\
\hline 1 & Cacat Releng & 42 & 41.2 & 4056 \\
\hline 2 & Cacat Bolong & 32 & 31.4 & 734 \\
\hline 3 & Cacat Runs & 28 & 27.5 & 1005 \\
\hline 4 & Total & 102 & & \\
\hline
\end{tabular}

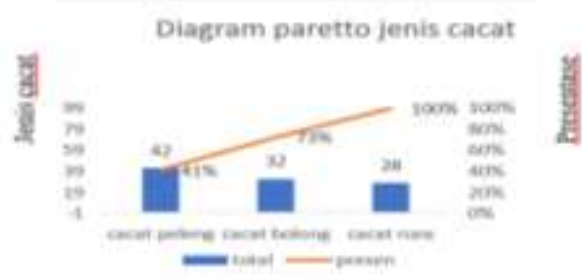

Gambar 4. Diagram Preto Data Tingkat Kecacatan Produk Pap Hanger

a. Analisis diagram pareto

Pada gambar diagram pareto diketahui jenis cacat yang

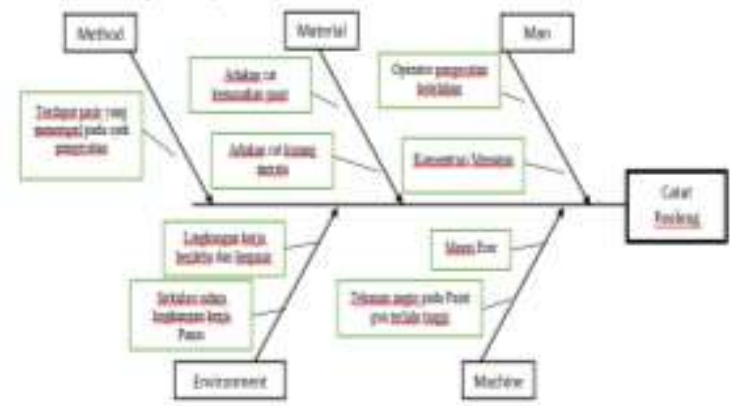

terjadi pada produk pap Hanger ada tiga yaitu peeling, bolong dan runs. Diketahui jenis cacat peeling memiliki nilai angka kecacatan tertinggi yaitu 42/800 atau 41,2\% disusul cacat bolong 32/800 atau 31,4 \% kemudian cacat Runs yang memilii total cacat $28 / 800$ atau $27,8 \%$.

b. Analisis DPMO dan nilai sigma

Berdasarkan table 8 yang merupakan hasil perhitungan DPMO dan Nilai Sigma 
diketahui nilai sigma tertinggi sebesar 3,381 dan terendah sebesar 3,129. Dilihat dari table 1 DPMO dan nilai sigma merupakan suatu alat untuk mengetahui level suatu produksi. Nilai sigma tertinggi adalah 6 dengan DPMO 3,4 yang artinya proses produksi tersebut hanya menghasilkan sebanyak 3,4 cacat untuk satu juta produknya. Jadi tingkat rata-rata industri di Indonesia adalah level 2- 3 sigma dan ratarata industri USA adalah 4- 5 sigma.

c. Analisis diagram fishbone

Menurut Nasution (2005) Diagram Sebab Akibat adalah suatu pendekatan terstruktur yang memungkinkan dilakukan suatu analisis lebih terperinci dalam menemukan penyebab-penyebab suatu masalah, ketidaksesuaian, dan kesenjangan yang terjadi. Diagram sebab dan akibat digunakan untuk mengidentifikasi dan menganalisis suatu proses atau situasi dan menemukan kemungkinan penyebab suatu persoalan/masalah yang terjadi. Analisis fishbone pada tahap ini di lakukan untuk mengetahui penyebab-penyebab suatu kegagalan yang terjadi pada produksi Pap Hanger di PT. Ravana Jaya ManyarGresik.

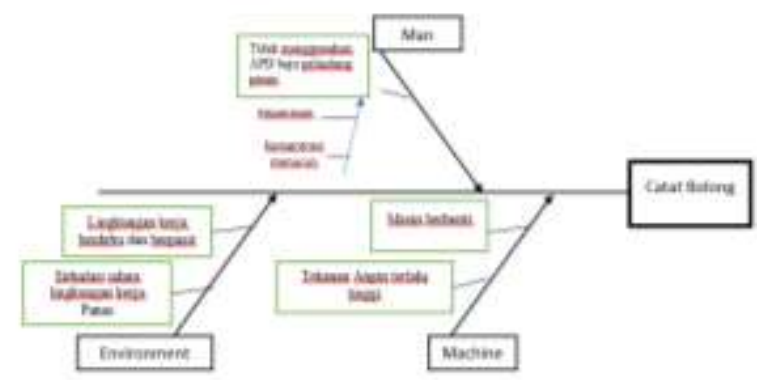

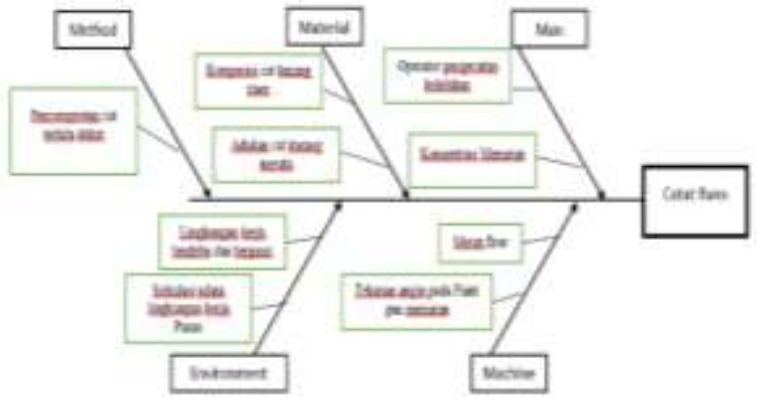

Gambar 7. Diagram Sebab Akibat Cacat Runs

\section{Improve}

Pada tahapan ini akan dibuat pemecahan suatu permasalahan serta membuat rekomendasi perbaikan proses produksi. dari hasil analisis pada cacat pap Hanger berdasarkan tahap yang sudah dilakukan sebelumnya pada diagram fishbone, pada tahap

Improve akan menggunakan pendekatan Failure Mode And Effect (FMEA). Berikut adalah hasil perhitungan dariproses FMEA kemudian diberikan usulan atau rekomendasi perbaikan pada penyebab kecacatan yang memiliki nilai RPN tertinggi.

Tabel 10. Nilai RPN Tertinggi

\begin{tabular}{|c|c|c|c|}
\hline Jenih cad & KCS Arowala & $\begin{array}{l}\text { Perechab } \\
\text { kreatulas }\end{array}$ & RPS \\
\hline Poveral & Ca krias keholeven & $\begin{array}{c}\text { Adikas out. } \\
\text { Setrateme pair }\end{array}$ & 212 \\
\hline Bobng & modak toicos & $\begin{array}{l}\text { Mesio cumtiry } \\
\text { Subtail }\end{array}$ & 210 \\
\hline $\operatorname{Rin}$ & $\begin{array}{l}\text { at ainzaspal of sti } \\
\text { titi }\end{array}$ & 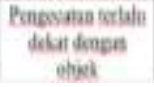 & 294 \\
\hline
\end{tabular}
dengan nilai RPN tertinggi, rekomendasi perbaikan pada permasalahan cacat produk Pap Hanger ini akan dicari menggunakan Langkah $5 \mathrm{~W} 1 \mathrm{H}$ sebagai berikut: 
Tabel 11. Usulan perbaikan menggunakan $5 \mathrm{~W} 1 \mathrm{H}$

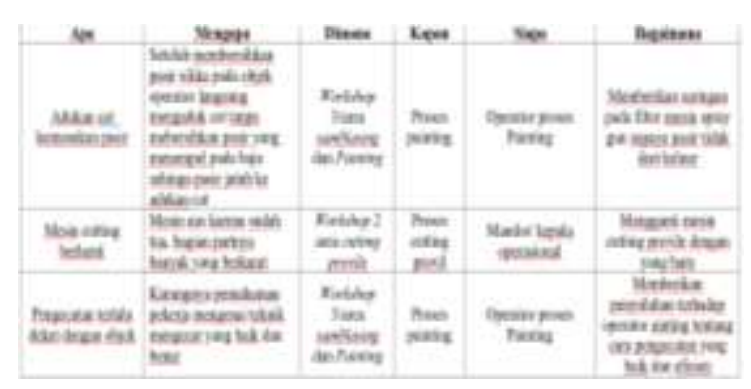

\section{KESIMPULAN}

Pada perhitungan Six Sigma didapatkan nilai DPMO serta Nilai Sigma. Nilai DPMO tertinggi yakni sebesar 51666,5 dan terendah 30000, nilai DPMO berarti jumlah cacat yang terjadi untuk satu juta kemungkinan atau per satu juta produksi. Pada perhitungan nilai sigma pada proses produksi Pap Hanger didapatkan nilai sigma antara 3,129 sampai 3,381 hal ini mengartikan bahwa proses produksi berada pada rata-rata industry Indoesia tetapi belum mencapai rata-rata industry USA.

Berdasarkan hasil proses FMEA serta perhitungan nilai RPN maka di buat rekomendasi perbaikan. Dari hasil perhitungan RPN didapatkan 3 penyebab dengan nilai tertinggi pada Adukan cat kemasukan pasir sebesar 252 dan rekomendasi perbaikan berupa memberikan saringan pada filter penyemprotan cat supaya pasir tidak ikut keluar, kemudian cacat bolong sebesar 210 dan rekomendasi perbaikan, kemudian cacat Runs sebesar 294 dengan rekmendasi perbaikan Memberikan penyuluhan kepada operator pengecatan cara mengecat dengan benar.

\section{DAFTAR PUSTAKA}

Gasperz Vincent. 2002. "Pedoman Implementasi Program Six sigma Terintegritas dengan ISO", 9001 : 2000, MBNQA dan HACCP. 82 Penerbit PT. Gramedia Pusaka Utama, Jakarta.

Garvin Dvid A, (1988). Managing Quality, The New York Press.

Nadifa, 2020. Analisis Penyebeb Kecacatan Kerudung Menggunakan Metode Six Sigma Pada UMKM Arryna Raya Manyar.Jurusan Teknik Industri, Fakultas Teknik, Universitas Muhammadiyah Gresik, Gresik.

Stamatis, D.H. 2003. Failure Mode and Effect Analysis : FMEA from theory to execution. American Society for Quality.

Sirine, Hari dan Elisabeth (2007, 03 September). Pengendalian Kualitas Menggunakan Metode Six Sigma (Studi Kasus Pada Pt Diras Concept Sukoharjo. Salatiga : Asian Journal of Innovation and Entrepreneurship.

Wahyu Djalmono Putro, dkk." Perbaikan Kualitas Proses Produksi Dengan Metode Six Sigma Untuk Mengurangi Cacat Produk Pada Partmaster Cylinder Tipe $2 d p \quad D i$ Departemenpainting Pt. Chemco Harapan Nusantara Cikarang", Teknik Mesin Produksi dan Perawatan, Politeknik Negeri Semarang, Semarang.

Winarni, Joko Susetyo dan Sariyono,2018." Analisis Pengendalian Kualitas Produk Kertas Dengan Menggunakan Metode Six Sigma, Fta Dan Fmea Untuk Usulan Perbaikan Kualitas Produksi”, ISSN: 1979-911X. Jurusan Teknik Industri, Fakultas Teknologi Industri, Institut Sains \& Teknologi AKPRIND Yogyakarta. 